\title{
THE EFFICIENCY OF SUBJECTIVE WELL-BEING: A KEY OF LATIN AMERICAN DEVELOPMENT
}

\author{
PABLO BEYTÍA \\ Chapter of: Bula, G. \& Masaheli, M. (forthcoming). Latin American perspectives \\ on global development. Cambridge: Cambridge Scholars Publishing.
}

(Last author's version)

\begin{abstract}
This chapter compares the development of Latin American countries with that of traditionally developed nations, based on several international indicators of well-being and sustainability that have emerged in the last decade. It is argued that in Latin America there is a specific type of development, which could be understood as an alternative path to the traditional model of social progress. The key to understand this type of development would be "the efficiency of subjective well-being": people get high happiness and life satisfaction with lower economic, state and environmental costs than in traditionally developed countries. It is suggested that the cohesion and quality of family ties is a key factor to explain this particular form of development: in Latin America the family has a relevant role in social security and at the same time would be important to explain the outstanding levels of subjective well-being.
\end{abstract}

Key words: development, social progress, Latin America, subjective well-being, happiness, life satisfaction, sustainable development.

\section{Introduction}

Since the mid-1940s, international public policies have been guided by a development model oriented to maximizing economic growth, which was supplemented half a century later with the aim of improving basic health and education conditions in the countries (Costanza et al 2009, UNDP 1990). Looking at these dimensions, Latin America was easily cataloged as a "developing" region, because its nations traditionally have shown a medium-low level of income and a human development close to the international average. This appellative helped to interpret the countries of the region as incomplete welfare projects, because despite their advances in health, education and poverty alleviation (ECLAC 2015, Rojas and García 2017), they have not yet reached the level of economic, health and educational prosperity that characterizes the so-called "developed" nations (Beytía 2016). In that sense, Latin America has been associated in the last decades with a type of development without identity, which could only be distinguished by the negation of the radical poles of progress: it is not an extremely poor region, nor where there are world examples of social wellbeing. 
But, is this story about the Latin American development acceptable nowadays? The answer to this question depends on the validity currently given to traditional development indicators. If GDP per capita, the Human Development Index and the more generalized indicators of health and education are still used in order to observe social progress, the description of Latin America as an incomplete development project remains consistent: almost without exception, the region is effectively located in the intermediate range of these measures (World Bank 2015, UNDP 2015). However, the unique use of these indicators to measure social progress has become highly debatable in recent years (Stiglitz, Sen and Fitoussi 2009; Rojas 2011), and three factors have contributed strongly to this situation:

1. The environmental problem: since the second half of the 20th century, ecological discourse has challenged the traditional model of social progress, because highly industrialized countries tend to have a high negative impact on the environment. Through the idea of a "sustainable economy" -strongly positioned by the UN since the 1980s-, an attempt to perfect the development model based primarily on national productivity has been made. (Ramírez, Sánchez y García 2004; Chouinard, Ellison y Ridgeway 2011).

2. The proliferation of new multidimensional indicators of development: in the last decade, many indicators of welfare, well-being and social progress have emerged -such as the Sustainable Society (2006), Happy Planet (2006), OECD Better Life (2011) or Social Progress (2013) indexes- which emphasize the importance of development dimensions previously not considered and also allow more detailed comparisons between countries and regions.

3. The increasing interest in subjective well-being indicators: also in the last decade the use of subjective indicators of quality of life -e.g. measures of happiness, life satisfaction or positive emotions (Beytía and Calvo 2011)- has been increased, and these indicators do not always vary in coherence with economic, health or educational results of countries (Easterlin et al. 2010, Clark and Senik 2010). This situation has allowed discovering a high well-being in unexpected regions and questioning the consistency of the traditional model of progress (Beytía 2015; Beytía 2016).

On the one hand, all these elements have helped to understand the blind spots of traditional development indicators. The emergence of new social indicators has clarified that the old measures of progress highlighted very precise areas of quality of life, which are far from representing social well-being as a whole. On the other hand, ecological critique and the new indicators of well-being have allowed to understand that the traditional model of development is not exempt of harmful consequences: in the industrial societies of the late modernity new risks, contingencies and social dangers have been generated (Giddens, Bauman, Luhmann and Beck 1996). And also, have not particular deficiencies and pathologies arisen in countries that primarily pursue, for their citizens, a long and 
educated life that contributes to sustained economic growth? (Han 2011; Han 2015).

In short, the new arena of social indicators allows us to pay attention to blind spots and harmful consequences of the traditional model of social progress. Along with this, a completely different diagnosis about Latin American development emerges. The region, from this renewed perspective, does manifest a particular identity. It no longer represents an incomplete project of development or an intermediate moment between the lack and the social prosperity, but it acquires a more realistic image: that of a group of countries with ambivalent development, where deficiencies in quality of life coexist with exceptional characteristics of well-being. These last characteristics could even positioning Latin America as an international positive example of development.

But, what are the aspects that make it possible to clarify the identity of Latin American development? And which of them contrast with the traditional model of development? The purpose of this chapter is to answer these questions by holding a main thesis: in Latin America there is a type of development with a particular identity that can be understood as an alternative way to the traditional model of social progress, since it is based on a different social infrastructure and presents a particular organization of collective costs and benefits. The main ingredients that allow us to understand the particular Latin American development would be three: 1) high subjective well-being (happiness, life satisfaction and positive experiences) in the population, 2) which is obtained with lower economic, state and environmental costs than in the traditionally developed countries, and 3) this situation is partly explained by the special cohesion and quality of family ties in the region. All these elements, however, could be synthesized through a single idea: the high efficiency of Latin American subjective well-being.

\section{The extraordinary consistency of the traditional development model}

Since the Bretton Woods International Conference, in 1944, nations around the world have increasingly used GDP per capita as an indicator of economic development (Costanza et al 2009). At the time of designing this measure, the experts specified that it was not a general indicator of social well-being and that it was even a limited way of diagnosing economic progress (Kuznets 1934). However, because its advance as a highly standardized international indicator, it gradually became the most widely used measure to diagnose the overall development of countries and to assess global patterns of social progress. In practice, states have not only used GDP per capita to develop fiscal budgets, monetary policies and economic performance diagnostics (McCulla and Smith 2007), but also to assess and compare the overall level of citizen welfare. This convention was historically strengthened by large interstate organizations -the World Bank, the International Monetary Fund and the United Nations- which since the second half of the 20th century have popularized country development 
ratings based largely on national production levels (Fantom 2016 IMF 2015, UNDP 2015) ${ }^{1}$.

Only in 1990 was a relevant international effort made to complement the information of GDP per capita with other standardized indicators of social welfare. The result of this effort was the Human Development Index, promoted by the United Nations in the last decades. The main objective of this multidimensional indicator was to shift the perspective of development, from a focus on income, wealth, production of consumer goods and capital accumulation to a focus oriented in people and its opportunities or deprivations (UNDP 1990). This project undoubtedly succeeded in broadening the discussion of social progress towards new dimensions - especially health and education - and also promoted the use of non-economic welfare indicators, such as life expectancy and average years of schooling. Along with this, it inspired interesting theoretical proposals on development, which augured the beginning of a new stage in the evaluation of international social progress, in which the human being would no longer be considered only as a homo aconomicus and would come to be understood from a holistic and multidimensional perspective (e.g. Max-Neef, Elizalde and Hoppenhayn 1993).

But this progress, which sought to become a tool for reforming social development, in practice ended up being a powerful instrument for validating the interpretation of social progress centered on the economic dimension. After all, the Human Development Index incorporated GDP per capita as an approximation to economic well-being, and complemented that information with health and education indicators that are strongly correlated with economic production (McGillivray 1991). The result, as can be seen in Table 1, is that the Human Development Index shows an almost perfect correlation with the capita GDP of the nations (it weights 0.959 on a scale between 0 and 1), whereby it contributes very little additional information to the wide economic classifications of international development: the higher GDP per capita, the greater human development in countries. The same is true for the more generalized measures of health and education development: the higher economic productivity, the more life expectancy (correlation of 0.856 ) and average years of schooling in nations (correlation of 0.840 ).

\footnotetext{
${ }^{1}$ Since the 1960s, the World Bank has distinguished between "developed" and "developing" countries based on national production, and has only recently challenged this classification (Fantom 2016). An analogous distinction is used by the International Monetary Fund -which separates "advanced economies" from "emerging and developing market economies" (IMF 2015)-. The United Nations Development Program also ranks countries using GDP as one of its main indicators (UNDP 2015, UNSD 2016).
} 
Table 1. Relation between GDP per capita, Human Development and basic indicators of health and education.

\begin{tabular}{l|cccc}
\hline & $\begin{array}{c}\text { GDP/capit } \\
a\end{array}$ & $\begin{array}{c}\text { Human } \\
\text { Development } \\
(\$ P P P)\end{array}$ & $\begin{array}{c}\text { Average Life } \\
\text { Expectancy }\end{array}$ & $\begin{array}{c}\text { Mean years of } \\
\text { schooling }\end{array}$ \\
\hline GDP/capita (\$PPP) & & $0,959^{* *}$ & $0,856^{* *}$ & $0,840^{* *}$ \\
Human Development Index & $0,959^{* *}$ & & $0,914^{* *}$ & $0,911^{* *}$ \\
Average Life Expectancy & $0,856^{* *}$ & $0,914^{* *}$ & & $0,748^{* *}$ \\
Mean Years of Schooling & $0,840^{* *}$ & $0,911^{* *}$ & $0,748^{* *}$ & \\
\hline
\end{tabular}

Sources: World Bank 2016 (GDP), UNDP 2015 (HDI, ALE and MYS).

Note: ** Correlation (Spearman Rho) is significant at the 0.01 level (bilateral). N: 140.

The intense relationship between GDP per capita and the Human Development Index -the most traditional and cross-country indicators of international development- can be seen more clearly in Graphs 1 and 2. As the first graph shows, the relationship between both indicators in the world generates a curvilinear pattern: among the poorer nations, small differences in GDP per capita mark high advances in human development, but this relationship declines when countries have higher incomes (see Graph 1). In other words, the relationship between GDP per capita and human development is expressed logarithmically, but with a very high degree of correlation (see Graph 2).

Graph 1. Correlation between GDP and Human Development

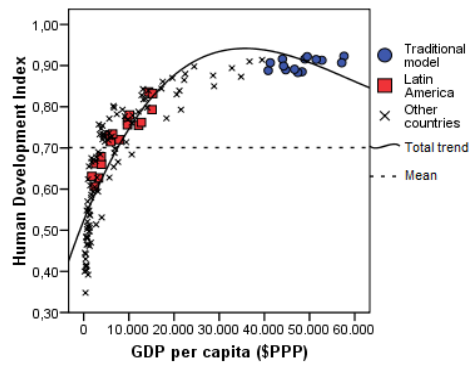

Graph 2. Correlation between logarithm of GDP and Human Development

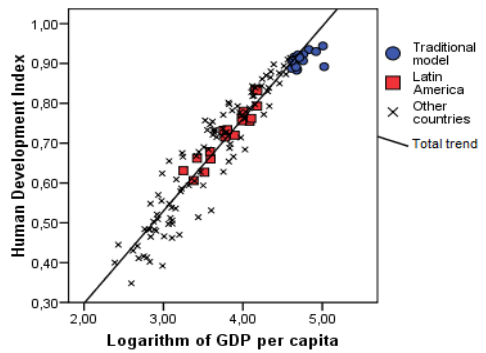

Sources: World Bank 2016 (GDP), UNDP 2015 (HDI). 
On the other hand, both graphs highlight the countries of Latin America (red squares) and those nations that could currently be classified as world models of traditional development (blue circles) -defined here as those that have high incomes according to World Bank classification 2016 and very high human development according to the United Nations ranking $2015^{2}-$. As can be seen through these traditional development variables, Latin American countries appear essentially as an intermediate group: they are not the poorest nor the richest; neither do they have high or low human development. They seem, in effect, an "incomplete project": a group of nations "on track" to obtain the whished standard of living.

These traditional indicators, on the other hand, show a high consistency with several aspects relevant to the quality of life and the social progress of countries. In addition to life expectancy and average years of schooling (see Table 1), there is some correlation with the level of violence: the greater economic and human development, the higher levels of social peace tend to have nations (see Graph 3). Consistent with this, Latin American countries (red squares) show higher rates of violence than high-income countries (Global Peace Index 2016).

Graph 3. Correlation between GDP and Global Peace Index

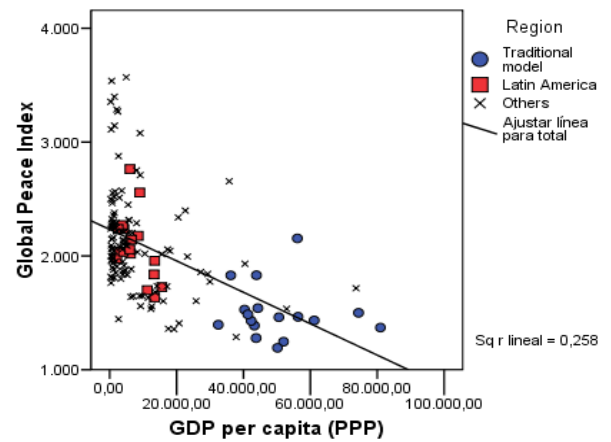

Sources: World Bank 2016 (GDP), Vision of Humanity 2016 (GPI).

Note: The greater the Global Peace Index, the less social peace.

If this result is added to the previous ones, a conclusion could be reached: economy, education, health and social peace advance together in countries, becoming particular manifestations of a transversal process of social progress. As we have seen, this idea finds important empirical support in traditional development indicators, due to the extraordinary consistency between various standardized measures at world level. In addition, this evidence implicitly

\footnotetext{
${ }^{2}$ Traditional development models, according to this empirical classification, would be the following: Australia, Austria, Belgium, Canada, Denmark, Finland, France, Germany, Iceland, Ireland, Japan, Luxembourg, Netherlands, Norway, Sweden, Switzerland and the United States.
} 
promotes a normative idea: all kinds of social progress should point in the same direction as these indicators, which together point to a path of development free from ambivalence or unwanted consequences. But, is this idea valid and congruent with the new indicators of international development?

\section{The unexpected pattern: the surprising levels of Latin American subjective well-being}

As we have seen, the traditional model of development makes it possible to distinguish very clearly Latin American countries from those that have been established as international models of social welfare. Compared with the latter, Latin American nations have worse results in terms of economy (GDP per capita), health (nutrition, infant mortality, life expectancy), education (literacy, reading rate, participation in primary and secondary education) and public security (homicide rate, violence cases), among other comparable aspects (World Bank 2016, CIA 2016, Social Progress Imperative 2016, Gapminder 2016, Global Peace Index 2016).

However, when the emerging development indicators are observed appears something striking: despite its comparatively low levels of objective social welfare, Latin American countries have similar or even higher subjective wellbeing levels that successful nations in the traditional development model (Beytía 2016, Rojas and García 2017). As can be seen in the graphics set 1, the percentage of highly happy people tends to be higher in Latin America compared to the group of nations that stands out internationally for its high GDP per capita and high human development. A similar situation can be seen when national averages of life satisfaction are compared (see Graphics set 1). 
Graphics set 1. Correlation between traditional development and subjective well-being

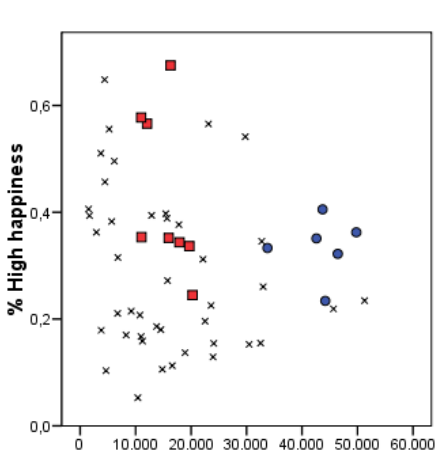
indicators
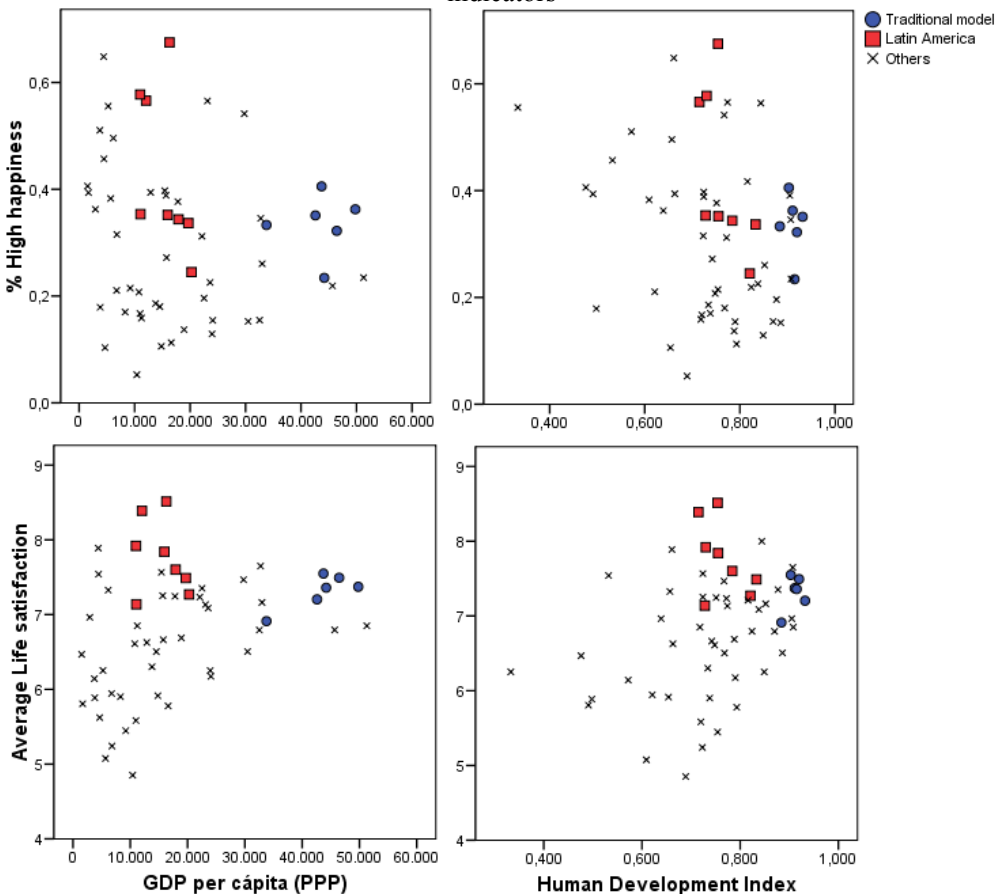

Sources: World Values Survey Association 2010-2014 (happiness), Gallup 2016 (life satisfaction), World Bank 2016 (GDP per capita) and UNDP 2015 (Human Development Index).

What these indicators indicate is consistent with several studies that in recent years have highlighted the high levels of subjective well-being of Latin Americans (Inglehart et al., 2008, Beytía 2011, Helliwell and Wang 2012, Clifton 2012, Beytía 2016, Rojas and García 2017). What these studies have clarified is that in Latin America there is a high percentage of people who claim to be very happy, and that the average level of life satisfaction is higher than in other regions of the world (Melgar and Rossi 2011; Rojas 2012; Calvo et al. 2012). Along with this, Latin Americans often report strikingly high levels of positive emotions: according to the results of the Gallup Survey 2015, eight of the ten nations with the highest concentration of positive experiences in the world belong to Latin America ${ }^{3}$, a situation that is consistent with previous versions of the same poll (Gallup 2016). In line with all this, the nations of the region have, on average, a suicide rate that is

\footnotetext{
${ }^{3}$ In order: Paraguay, Guatemala, Honduras, Ecuador, El Salvador, Costa Rica, Uruguay and Colombia.
} 
lower than the international average, and certainly lower than that of the traditionally developed nations (Social Progress Index 2016) ${ }^{4}$.

Therefore, the accumulated evidence is clear and consistent: Latin America stands out worldwide for its intense concentration of subjective well-being. This can be seen in various indicators -happiness, life satisfaction and positive emotionswhich in turn are related to an objective sign of psychological well-being -low suicide rates-.

\section{The efficiency of Latin American subjective well-being}

On the other hand, Latin American countries achieve these surprising levels of subjective well-being at a lower environmental cost than the traditionally developed countries. As show the Graphics set 2, the greater the economic development -and therefore the human development-, the nations have both a greater ecological footprint and higher emissions of carbon dioxide. If we approach ecological damage from these indicators, we can conclude that the type of development characteristic of Latin American countries assumes lower environmental costs than that of traditionally developed countries (although there also seem to have less public concern in ecological care ${ }^{5}$ ).

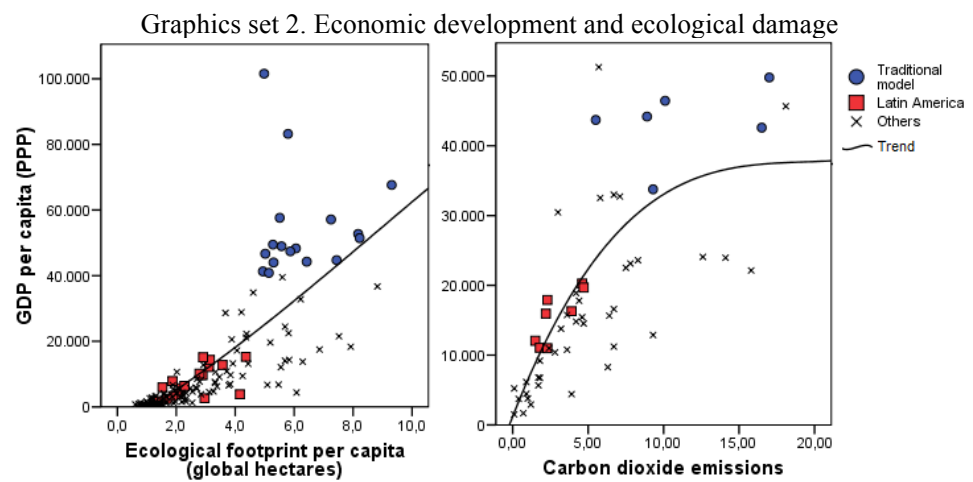

Sources: World Bank 2016 (GDP), Global Footprint Network 2016 (ecological footprint) and Vision of Humanity 2016 (carbon dioxide emissions).

\footnotetext{
${ }^{4}$ According to data included in the Social Progress Index 2016, the average suicide rate of the nations included in the study is 11.21 (per 1,000 habitants). This rate amounts to 11.86 in the case of traditionally developed countries, while in Latin America it is 8.86.

${ }^{5}$ An indication of this is found in water care: with the exception of Chile, there are very low levels of wastewater treatment in Latin America, and considerably lower than in the traditionally developed countries (Social Progress Index 2016).
} 
As can be seen, Latin American countries produce a level of environmental damage that is in proportion to their per capita production level. Therefore, it should not be assumed that in Latin America there is a more sustainable model of economic development, but that the nations of the region have less ecological consequences probably due to their lower concentration of economic activity.

However, the interesting thing is that with these comparatively low levels of GDP per capita, human development and environmental damage, these countries achieve comparatively high levels of happiness and life satisfaction. In other words, one of the most original characteristics of Latin American development is the efficiency of its subjective well-being: with low utilization of economic, state (health and education) and environmental resources, people declare very positive evaluations about their lives. The Graphics set 3 shows the high sustainability of the Latin American subjective well-being, since countries of the region obtain high levels of happiness and life satisfaction at a low ecological cost:
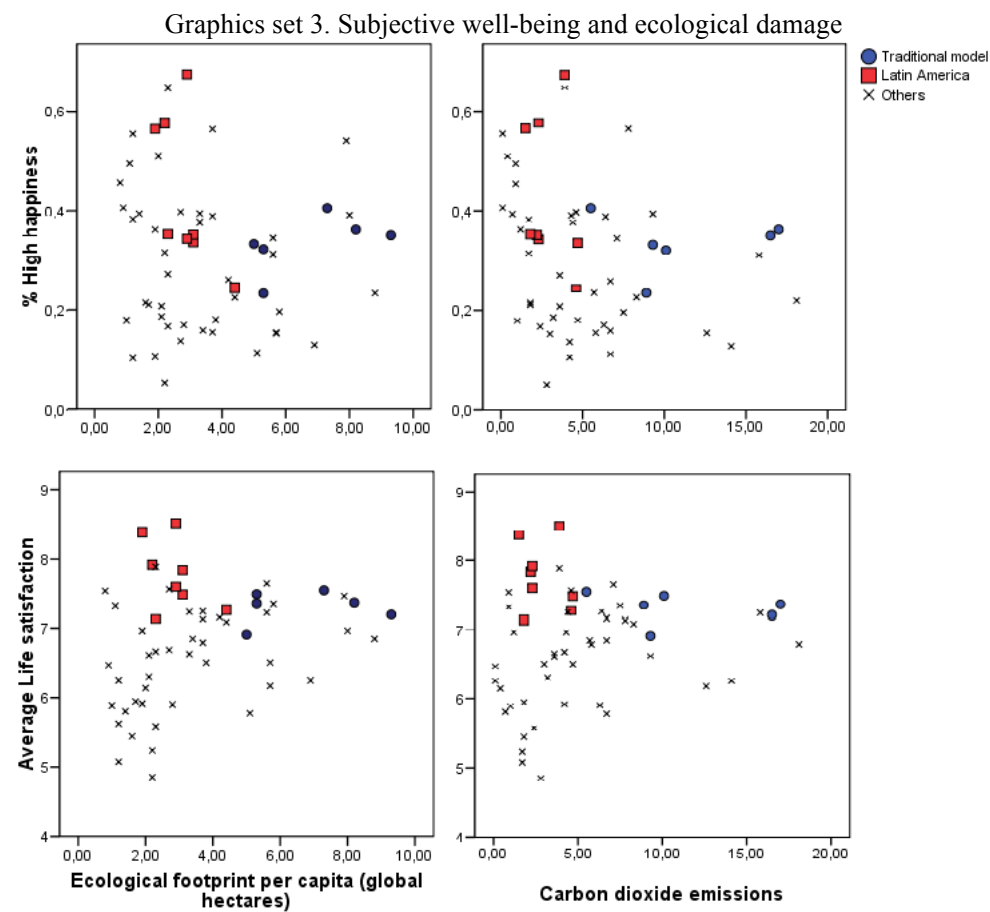

Sources: World Values Survey Association 2010-2014 (happiness), Gallup 2016 (life satisfaction), Global Footprint Network 2016 (ecological footprint) and Vision of Humanity 2016 (carbon dioxide emissions).

In recent years, the New Economics Foundation has emphasized this same idea through the Happy Planet Index. According to this new indicator of social 
progress, Latin American countries would be no less than a world example of development: they that obtain the most beneficial relationship between achieving a long and happy life, coupled with a low environmental cost (New Economics Foundation 2016).

But more generally, the efficiency of Latin American subjective well-being can be assessed by calculating in nations the proportion between their declarations of happiness and/or satisfaction with life, versus the social and ecological cost involved in their development processes. To explain this point properly, we can use as an example the cases of Brazil and Australia. Both countries have almost the same percentage of people who claim to be very happy (35\%) according to the latest wave of the World Values Survey (2010-2014). However, Brazil achieves this percentage with a GDP per capita close to 15,951 dollars, while Australia with approximately 42,506 dollars per person. In that sense, happiness in Brazil could be considered 2.7 times more efficient than the happiness of Australia in terms of the use of economic resources. In other words, Brazil achieves the same levels of high happiness with a less productive economy.

The same exercise can be done to compare the results of the traditional development model versus those of Latin American countries. As can be seen in Graphics set 4, Latin America (red lines) tends to obtain subjective well-being (considering happiness and satisfaction with life $^{6}$ ) at a lower cost in economic development, human development and environmental resources than the traditionally developed nations Blue).

\footnotetext{
${ }^{6}$ This subjective well-being indicator is calculated by combining in a single indicator the declarations of happiness and life satisfaction of each country, in the manner proposed by Inglegart et al $(2008$, p. 267): "because life satisfaction is measured on a 10-point scale and happiness is measured on a 4-point scale, and because the two questions have opposite polarity, the SWB composite was constructed as follows: SWB = life satisfaction $-2.5 \mathrm{x}$ happiness".
} 
Graphics set 4. Efficiency of subjective well-being (SWB): proportion of SWB versus GDP, HDI and Ecological Footprint
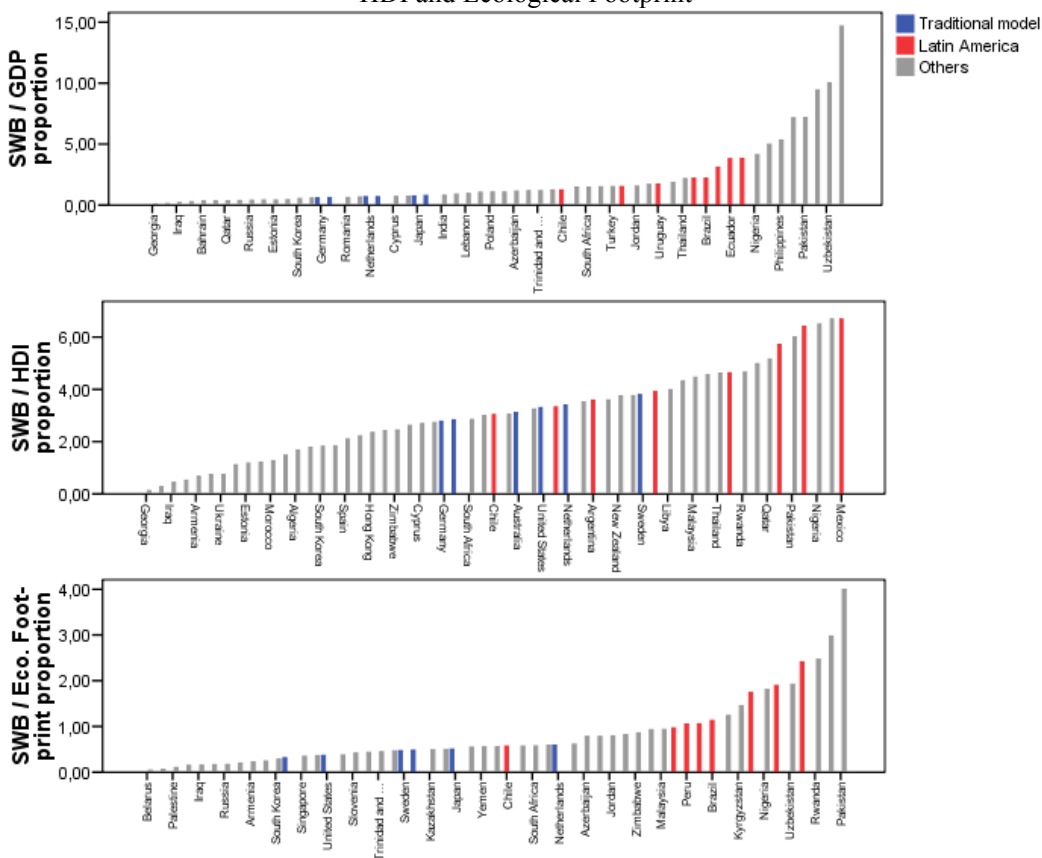

Sources: World Values Survey Association 2010-2014 and Gallup 2016 (SWB), World bank 2016 (GDP), UNDP 2015 (HDI), Global Footprint Network 2016 (ecological footprint).

Note: For calculating the relationship between SWB and GDP, the second was divided by 10,000 to facilitate observation of the data.

\section{The background of the efficiency: less centrality of income and greater family cohesion}

But why does Latin America get so much subjective well-being at such a low economic, state (human development) and environmental cost? That seems to be one of the most intriguing questions about the development of the region and for the moment it can only be partially answered. I would like to emphasize two complementary arguments that have been developed empirically in previous research.

First, there is a negative response: compared to the population of traditionally developed countries, the happiness of Latin Americans is lesser related to income level and financial satisfaction (Beytía 2011; Beytía 2016). In other words, the degree of happiness of the people in the region is less dependent on the economic situation of their homes. This may explain, in part, the apparent "paradox of Latin 
American well-being": that these countries of moderate production (and by extension, modest human development) achieve the highest standards of happiness worldwide. Assuming, in addition, the extraordinary consistency of the traditional model of development (see Table 1 and Graphics 1, 2 and 3), it could be more generally suggested that Latin America's subjective well-being depends to a lesser extent of the advances in the traditional route of progress.

This argument helps to clarify why in Latin America a medium-low GDP per capita is not a barrier to obtain high levels of subjective well-being. However, it does not explain the origin of high happiness and life satisfaction in the region. And here comes a complementary argument, which points to the social infrastructure of Latin American development.

If the construction of the traditional development route is historically followed, it will be seen that in the last seven decades the "most advanced" countries transformed the social base on which they organized development and security. They went from having a system of "proximity protection" -where security was held mainly by members of a family community (Castel 2003) - to a system of "welfare states" -which allow people to be less dependent on their community associations (Esping-Andersen 1990)-. In this change, the state gradually acquired greater attributions in health, education and private economy problems that had previously been solved by the family and the intimate social circles. In that sense, it gradually replaced the network of primary links as an organizational center of development, since it was no longer an indispensable element in maintaining the survival and material sustenance of population.

This change undoubtedly had positive consequences for the development of countries (for example, it made it possible to universally guarantee certain basic rights), but also created a system of "direct access" between the individual and the social whole (Taylor 2004) that favored the weakening of the intermediate links. The welfare state, in an unforeseen way, made the interaction and cohesion of the primary bonds dispensable: to obtain security and the necessary to survival, now it was enough to be a citizen.

In terms of subjective well-being, this change could have generated a comparative disadvantage. In recent years, various studies have emphasized that social interaction, and especially when it generates quality and cohesion bonds, is one of the most important keys to explaining happiness and life satisfaction (Bjørnskov 2003; Lucas and Dyrenforth 2006; Camfield, Choudhury and Devine 2006, Ram 2009, Demir and Davidson 2013, Soulsby and Bennet 2015). A great part of this literature could be summarized in a simple rule: the stronger the infrastructure for a high and comfortable socialization (in psychological, interpersonal and social terms), the higher is the probability of individual happiness (Beytía, forthcoming).

And precisely in the sphere of social relations, Latin America seems to have a comparative advantage. Compared to traditional models of development, it still 
gives a high prominence to the network of family ties (Beytía 2016; see Table 2). The state undoubtedly presents in the region an essential role for the construction of social development; however, they are generally "weak states" (Centeno 2014), which have failed to displace primary links as guarantors of individual protection and well-being. Thus, in Latin America a mixed social welfare infrastructure is maintained, based not only on the direct and impersonal relationship between the individual and the state, but also on a personal network of exchanges and favors, based more on the reciprocity that in a formal system of contracts and social rights. This has favored the maintenance of family cohesion as a basic cultural pillar, which is fundamental for the promotion of subjective well-being in the region.

As can be seen in Table 2, except for a slightly lower percentage of stable couples -which should be interpreted considering the high remarriage rates of some developed countries ${ }^{7}$ - in Latin America there is a clear tendency to develop family relations and practices that are statistically associated to the unfolding of subjective well-being. This tendency is very relevant, especially if one considers that some experts have cataloged family relationships as the non-genetic conditions that have greater explanatory potential of subjective well-being (Layard 2005).

Table 2. Subjective well-being and family relationships

\begin{tabular}{|c|c|c|}
\hline & $\begin{array}{c}\text { Traditional } \\
\text { model }\end{array}$ & Latin America \\
\hline \multicolumn{3}{|c|}{ Subjective well-being } \\
\hline High happiness & $33,4 \%$ & $47 \%$ \\
\hline High life satisfaction (8 level or more) & $56,2 \%$ & $67,3 \%$ \\
\hline \multicolumn{3}{|c|}{ Indicators of family relationships } \\
\hline Married or cohabiting & $65,7 \% *+$ & $59,1 \% *+$ \\
\hline Divorced & $7,1 \% *_{-}$ & $3,3 \% *_{-}$ \\
\hline With child & $71,6 \% *+$ & $75 \% *+$ \\
\hline Three or more child & $22,3 \% *+$ & $34,2 \% *+$ \\
\hline Living with parents & $14,9 \% *+$ & $26,9 \% *+$ \\
\hline High importance of family & $88,9 \% *+$ & $91,5 \% *+$ \\
\hline Complete trust in family & $74,7 \% *+$ & $82,1 \% *+$ \\
\hline Goal of parental pride (strongly agree) & $17,3 \% *+$ & $44 \% *+$ \\
\hline
\end{tabular}

Source: World Values Survey (2010-2014).

*+: The correlation between this variable and subjective well-being is significant and positive.

*-: The correlation between this variable and subjective well-being is significant and negative.

If we look this data in detail, the following conclusions can be highlighted. Compared to the traditionally developed countries, in Latin America there is: a) a

\footnotetext{
${ }^{7}$ In the United States, for example, currently 4 out of 10 marriages include people who were previously married, according to data from the American Community Survey. This is important, because remarriage does not seem to have the same advantages of happiness as the first marriage, since it does not eliminate in the long term the high degree of dissatisfaction caused by divorce (Gardner, Jonathan and Andrew Oswald, 2005).
} 
composition of social bonds with a lower divorce rate, which implies less negative long-term effects on happiness; b) a greater density and cohesion of family ties more children and people living with their parents-, that is, a situation that favors family interaction and cohesion; c) some psychological dispositions that foster the development of satisfactory family relationships are more common - such as the high degree of trust in the family and the claim to achieve parental pride- ${ }^{\text {. All }}$ these characteristics are statistically associated with the greater subjective wellbeing of the population, both in the traditionally developed countries and in Latin America.

In short, Latin Americans seem to live in an family relationships ecosystem conducive to happiness, which gather low costs associated with marital disruption, along with the strengthening of family interactions in an environment of high mutual trust.

\section{Conclusion: towards a new understanding of Latin American development}

The foregoing analysis suggests that Latin America should no longer be classified lightly as a "developing" region. Faced with this assertion, which implicitly implies the existence of a single and consistent route of social progress, the most appropriate would be to ask: what kind of development is considered as a reference? If what is in mind is the traditional model of social progress, Latin America is undoubtedly still a region with intermediate results, which can be observed in economy, health, education and public security. However, these countries also tend to achieve the highest levels of happiness, life satisfaction and positive experiences in the world, at a lower monetary, human development and environmental cost than the traditionally developed countries. This is the main phenomena analyzed in this chapter: the extraordinary efficiency of Latin American subjective well-being.

Considering this particularity, Latin America should not simply represent an intermediate stage between absolute lack and high standards of living. Rather it could be seen as an alternative route of social well-being. More precisely, the Latin American development type differs from the traditional model in at least two relevant dimensions: the social infrastructure that drives welfare and the configuration of social benefits/costs of development.

In terms of social infrastructure that drives welfare, there are some key differences between the traditional model of development and that expressed in practice in Latin America. First, in Latin America the state does not have the same strength and efficiency as in the traditionally developed countries, and for that reason, family ties have continued playing a decisive role in ensuring social security. This implies that social welfare is still largely based on family cohesion -rather than on institutional confidence-. In this context, social security is often secured through 
personal ties and reciprocal favors, which encourages the internal cohesion of intimate circles. This personal mechanism is a complement of the state social solidarity, which in contrast tends to distributes benefits by legal/impersonal criteria and in a direct relationship between the state and each individual (see Table 3).

Table 3. Social well-being infrastructure

\begin{tabular}{|c|c|c|}
\hline $\begin{array}{c}\text { Principal welfare } \\
\text { agent(s) }\end{array}$ & Traditional model & Latin American model \\
\hline Base social capital & State & State and family \\
\hline Social security \\
bond & Impersonal, legal, individual. & $\begin{array}{c}\text { Cohesion and trust in family } \\
\text { relationships }\end{array}$ \\
$\begin{array}{c}\text { Impersonal, legal and } \\
\text { Personal, reciprocal and } \\
\text { cohesive (with family). }\end{array}$ \\
\hline
\end{tabular}

These distinctions are correlated with a number of differences in social outcomes: the type of Latin American development has a configuration of benefits and costs that differs substantially from that of traditionally developed countries. As is summarized in Table 4, Latin America has worse outcomes in economy, human development and public security, but a higher subjective well-being and a lower ecological impact.

Table 4. Social benefits and costs configuration

\begin{tabular}{|c|c|c|}
\hline & Traditional model & Latin American model \\
\hline Per capita income level & High & Medium-low \\
\hline $\begin{array}{c}\text { Human development } \\
\text { level }\end{array}$ & Very high & Medium-high \\
\hline Violence and homicides & Low rates & High rates \\
\hline Subjective well-being & Medium & High (and less suicides). \\
\hline $\begin{array}{c}\text { Environmental impact } \\
\text { (ecological foot-print and } \\
\text { carbon dioxide emissions) }\end{array}$ & High & Low \\
\hline
\end{tabular}

In logical terms, the comparison between both types of development can be clarified with the following mathematical formula, which establishes a relation between subjective well-being (SWB) and ecological sustainability (ES), on the one hand, and economic production (GDP), Human development (HDI) and public security (PS), on the other:

$$
\frac{\mathrm{SWB} \times \mathrm{ES}}{\mathrm{GDP} \times \mathrm{HDI} \times \mathrm{PS}}
$$

The result of this formula, according to the data reviewed in this chapter, tends to be higher in Latin American countries than in those that represent the traditional model of development. In other words, the Latin American model of development is characterized by the efficiency of its subjective well-being: it achieves high 
levels of happiness and life satisfaction at a lower ecological, economic and human development cost. This also implies that the region achieves these subjective wellbeing levels with higher rates of poverty, infant mortality, illiteracy and public insecurity.

In short, this analysis suggests that they are two different models of development, which are based on different social infrastructures and obtain different collective benefits/costs. While it would be possible to evaluate which of these routes is most beneficial according to certain particular criteria or objectives, it does not seem possible to choose a path free from ambivalence: both models, as strategies of social progress, incorporate specific opportunity costs and relative social deficiencies.

\section{Bibliography}

Beytía, P. (2011). El impacto del contexto social en los determinantes individuales de la felicidad: América Latina, Europa occidental y Estados Unidos en perspectiva comparada. Santiago de Chile: Pontificia Universidad Católica de Chile.

Beytía, P. (2015). El potencial político de la felicidad: fundamentos científicos y de aplicación gubernamental. Persona y Sociedad, Vol. XXIX, No 3.

Beytía, P. (2016). The singularity of Latin American patterns of happiness. In: Mariano Rojas (ed.). 2016. Handbook of Happiness Research in Latin America. Dordrecht: Springer.

Beytía, P (forthcoming). Vínculos familiares: una clave explicativa de la felicidad. In Reyes, C. \& Muñoz, M. La familia en tiempos de cambio. Ediciones UC.

Beytía, P. \& Calvo, E. (2011). ¿Cómo medir la felicidad? Claves de Politicas Públicas, No 4.

Bjørnskov, C. (2003). The happy few: Cross-country evidence on social capital and life satisfaction. Kyklos, 56, 3-16.

Calvo, E., Castellanos R., Martínez I., Millán, R., Moyano, E., Palomar, J., Rojas, M., Wills, E. \& Yamamoto, J. (2012). Medición, investigación e incorporación a la politica pública del bienestar subjetivo: América Latina. Mexico: Foro Consultivo Científico y Tecnológico.

Camfield, L., Choudhury, K., \& Devine, J. (2006). Relationships, happiness and well-being: Insights from Bangladesh. Wed Working Paper, 14 (Wellbeing in developing countries).

Castel, R. (2003). L'inse 'curite' sociale. Paris: E' ditions du Seuil.

Centeno, M. A. (2002). Blood and debt: War and the nation-state in Latin America. Pennsylvania: Penn State Press.

Center Intelligent Agency. (2016). The world factbook. Available at: https://www.cia.gov/library/ publications/the-world-factbook/

Chouinard, Y., Ellison, J., \& Ridgeway, R. (2011). The sustainable economy. Harvard Business Review, 89(10), 52-62. 
Clark, A., \& Senik, C. (2010). Will GDP growth increase happiness in developing countries? IZA Discussion Paper, N 5595.

Clifton, J. (2012). Latin Americans most positive in the world. Available at: http://www.gallup.com/poll/ 159254/latin-americans-positive-world.aspx

Costanza, R., Hart, M., Talberth, J., \& Posner, S. (2009). Beyond GDP: The need for new measures of progress. The pardee papers, $\mathrm{N}^{\circ} 4$.

Demir, M., \& Davidson, I. (2013). Toward a Better Understanding of the Relationship Between Friendship and Happiness: Perceived Responses to Capitalization Attempts, Feelings of Mattering, and Satisfaction of Basic Psychological Needs in Same-Sex Best Friendships as Predictors of Happiness. Journal of Happiness Studies, 14(2), 525-550.

Easterlin, R. A., McVey, L. A., Switek, M., Sawangfa, O., \& Zweig, J. S. (2010). The happiness-income paradox revisited. Proceedings of the National Academy of Sciences, 107(52), 22463-22468.

ECLAC (2015). Social panorama of Latin America. ECLAC Flagships.

Esping-Andersen, G. (1990). The three world of welfare capitalism. Cambridge: Polity Press.

Fantom, N. (2016). The 2016 edition of World Development Indicators is out: three features you won't want to miss. In: TheDATABlog of The World Bank (reviewed at 04/15/2016). Available at: http://blogs.worldbank.org/opendata/2016-edition-world-developmentindicators-out-three-features-you-won-t-want-miss

Gallup (2016). Gallup 2016 Global Emotions Report.

Gapminder (2016). Gapminder world. Available at: http://www.gapminder.org/world/

Gardner, J., \& Oswald, A. J. (2006). Do divorcing couples become happier by breaking up? Journal of the Royal Statistical Society: Series A (Statistics in Society), 169(2), 319-336.

Giddens A., Bauman Z., Luhmann N. \& U. Beck (Beriain J. Ed.) (1996). Las consecuencias perversas de la modernidad: modernidad, contingencia y riesgo. Barcelona: Anthropos.

Global Footprint Network (2016). Data and Results: National Footprint Accounts [webpage]. Retrieved from:

http://www.footprintnetwork.org/en/index.php/GFN/page/footprint_data and results

Han, B. C. 2011. Topologie der Gewalt. Berlin: Matthes \& Seitz.

Han, B. C. 2015. Müdigkeitsgesellschaft. Berlin: Matthes \& Seitz.

Helliwell, J., \& Wang, S. (2012). The state of world happiness. In J. Helliwell, R. Layard, \& J. Sachs (Eds.), World happiness report. New York: The Earth Institute Columbia University.

Inglehart, R., Foa, R., Peterson, C., \& Welzel, C. (2008). Development, freedom and rising happiness. Perspectives on Psychological Science, 3(4), 264285.

International Monetary Found (2015). Ajustándose a precios más bajos para las materias primas. Perspectivas de la economía mundial, Oct. 2015. 
Kuznetzs, S. 1934. National Income 1929-1932. A report to the U. S. Senate, 73rd Congress, 2nd Session. Washington, DC. US Government Printing Office.

Layard, R. (2005). La felicidad: lecciones de una nueva ciencia. México: Taurus.

Lucas, E., \& Dyrenforth, P. (2006). Does the existence of social relationships matter for subjective well-being? In K. D. Vohs \& E. J. Finkel (Eds.), Self and relationships: Connecting intrapersonal and interpersonal processes (pp. 254-273). New York: Guilford Press.

Max-Neff, M., Eelizalde, A., \& Hoppenhayn, M. (1993). Desarrollo a escala humana: conceptos, aplicaciones y reflexiones. Montevideo: Nordan Comunidad. Redes.

McCulla, S. H. \& S. Smith. 2007. Measuring the Economy: a primer on GDP and the national income and product account. Washington, DC: Bureau of Economic Analysis, US Department of Commerce.

McGillivray, M. (1991). The Human Development Index: yet another redundant composite development indicator? World Development, 19(10), 14611468.

Melgar, N., \& Rossi, M. (2011). Percepción Individual de Bienestar y Desempeño Macroeconómico. In M.Rojas(coord), La Medición del Progreso y del Bienestar. Propuestas desde América Latina. México: Foro Consultivo Científico y Tecnológico.

New Economics Foundation (2006). The Happy Planet Index. Available at: http://happyplanetindex.org/

New Economics Foundation (2016). The Happy Planet Index 2016. A global index for a sustainable wellbeing (briefing paper).

OECD (2011). Better Life Initiative: Measuring Well-Being and Progress. Available at: http://www.oecd.org/statistics/better-life-initiative.htm

Ram, R. (2009). Social capital and happiness: Additional cross-country evidence. Journal of Happiness Studies, 11, 409-418.

Ramírez, A., Sánchez, J. M. \& García, A. (2004). El Desarrollo Sustentable: Interpretación y Análisis. Revista del Centro de Investigación, Vol. 6, núm. 21, pp. 55-59.

Rojas, M. (2011). Más allá del ingreso: progreso y bienestar subjetivo. In M. Rojas (coord.), La medición del progreso y del bienestar: propuestas desde América Latina (pp. 29-40). México D.F.: Foro Consultivo y Tecnológico.

Rojas, M. (2012). El Bienestar Subjetivo en América Latina. In M. Puchet, M. Rojas, R. Salazar, F. Valde's, \& G. Valenti (Eds.), América latina en los Albores del Siglo XXI: Politica, Sociedad y Economía. México: Facultad Latinoamericana de Ciencias Sociales.

Rojas, M. \& García, J. J. (2017). Well-Being in Latin America. In Estes, R. \& Sirgy, J. The Pursuit of Human Well-Being, pp. 217-255.

Social Progress Imperative (2016). Social Progress Index. Available at: http://www.socialprogressimperative. org/data/spi

Soulsby, L. \& Bennett, K. (2015). Marriage and Psychological Wellbeing: The Role of Social Support. Psychology, 2015, 6, 1349-1359. 
Stiglitz, J. E., Sen, A. K., \& Fitoussi, J. P. (2009). Rapport de la Commission sur la mesure des performances économiques et du progrès social.

Sustainable Society Foundation (2006). Sustainable Society Index. Available at: http://www.ssfindex.com/ssi/

Taylor, C. (2004). Modern social imaginaries. Durham: Duke University Press.

UNDP (1990). Human development report 1990. New York: Oxford University Press.

UNDP (2015). Human development report 2015. Washington D.C.: Communications Development Incorporated.

Vision of Humanity (2016). Global Peace Index. Available at: http://static.visionofhumanity.org/

World Bank (2015). World Bank annual report 2015.

World Bank (2016). World Bank annual report 2016.

World Values Survey Association (2014). World Values Survey Wave 6 2010-2014 Official Aggregate v.20150418 (www.worldvaluessurvey.org). Aggregate File Producer: Asep/JDS, Madrid SPAIN. 